\title{
EVALUATION OF MORPHOLOGICAL DIVERSITY OF LUPINUS ANGUSTIFOLIUS L. DEPENDING ON GROWTH STAGES
}

\section{Vlasova Elena}

SSI All-Russian Breeding and Agrotechnological Institute of Horticulture and Nursery, Moscow, Russia

\author{
Received 26. 62017 \\ Revised 29.6. 2017 \\ Published 30.11.2017
}

\begin{abstract}
Based on the results of long-term description of VIR collection of Lupinus angustifolius L. it was found that the intensity of phenotypic expression of the some morphological features depends on the growth stage of plant. Meanwhile, the intraspecific classification is based on a visual assessment of morphological signs. The corolla coloring and the painting on the seed testa characterize the species. The color of cotyledon and vegetative organs and the presence or absence of anthocyanin on the keel petal are the diagnostic signs of the subspecies. In addition to the diagnostic characters of the classification, there are also a number of features of intraspecific diversity, some of which are very useful in crop breeding. These are the type of branching, the color of endocarp and the width of leaf. In this regard the available numeral system of lupin growth stages was complemented with data of the estimated morphological traits of Lupinus angustifolius by growth stages. These data are presented in a tabular format. Also, data on the regularity of manifestation of the features during the growing season are presented in that Table. The presented Table would contribute to the unification of monitoring of the morphological descriptions at a time of subjective visual perception. It can also help newcomers to correctly assess the intraspecific diversity of Lupinus angustifolius.
\end{abstract}

Keywords: blue lupine; morphological signs; growth stages; diversity; phenotyping

\section{Introduction}

A VIR collection of Lupinus angustifolius L. includes over 840 samples. The samples of Lupinus angustifolius are characterized by a wide phenotypic diversity. All above-ground vegetative and reproductive organs of plants (the cotyledons, stem, leaves, buds, flowers, pods, seeds) have a variety of morphological markers, which make up the individual characteristics of each sample. Intraspecific diversity of species based on morphological features presented in the existing intraspecific classification (Kurlovich and Stankevich, 1990; Kurlovich, 2002; Kuptsov and Takunov, 2006) which however requires incorporation of a number supplements (Vlasova, 2012, 2015). The present taxonomy of Lupinus angustifolius includes 29 species, 16 subspecies, 25 determinant and 2 fasciated forms. The taxonomically important features are divided into basic and additional. The both basic signs: the corolla coloring and the painting on the seed testa characterize the species. The additional features such as the color of cotyledon and vegetative organs, the presence or absence of anthocyanin on the keel petal are the diagnostic signs of the subspecies.

*Corresponding author: Elena Vlasova, SSI All-Russian Breeding and Agrotechnological Institute of Horticulture and Nursery, Moscow, Russia, $\square$ stevlas@yandex.ru 
An important feature, loosely covered the existing intraspecific taxonomy, is the type of branching. Only determinant and fasciated morphotypes isolated in the rank of form, despite the fact that Kuptsov N.S. proposed 7 model types of the diverse habit: wild, pseudo-wild, quasi-wild, corymbose, paniculate, palm-like, spike-like. The formation of these model types is associated with the reduction of branching of the first, second and subsequent orders (Kuptsov, 2001).

There are signs which are not taxonomically important, but are also useful in crop breeding as well as in genetic, botanical, physiological researches. Among the signs visible to the human eye these are the presence or absence of anthocyanin on the peduncle of the flower raceme and around the edges of leaflets, the color of endocarp, the width of leaflets, the abundance of trichomes on leaves and pods. The color of endocarp of the pod, for example, is a breeding sign, because its red-brown color is a marker of the presence of gene le (the resistance to the pod cracking) (Gladstones, 1967).

The intensity of phenotypic expression of the some morphological features depends on the growth stage of plant. In this regard, it would be useful to establish a schedule for phenotyping of Lupinus angustifolius stocks.

\section{Materials and methodology}

The 840 samples of Lupinus angustifolius of VIR collection were grown in field trial in climatic conditions of the Moscow region (Russia) from 2000 to 2016. Since the expression of the morphological traits in the varying degrees influenced by the external conditions, each sample was grown until maturation at least three times during this period. The descriptors for the genus Lupinus L. (Stepanova et al., 1985), the intraspecific classification (Kurlovich and Stankevich, 1990; Kurlovich, 2002; Kuptsov and Takunov, 2006; Vlasova, 2015), the information about genetics of morphological signs (Kuptsov, Takunov, 2006) were used to characterize of the samples. The numeral system of the lupin growth stages (Dracup and Kirby, 1996) with modifications (Walker et al., 2011) was used.

\section{Results and discussion}

The lupin is a dicotyledonous plant that characterized by epigeal emergence above the soil surface. The cotyledons are green from bright to dark, yellow-green or purple at the abaxial side. The cotyledons are as a rule dark-green and can be covered in purple spots at the adaxial side. Different shades of green color are also characteristic for leaves. The leaves turn purple at the adaxial side in the presence of anthocyanin. It is often the anthocyan is present around the edges of leaflets.

There are four main colors of the corolla, which are the diagnostic features in the intraspecific classification: the white, the blue, the pink, the pale violet. There are different shades of a main colors. In addition, the color spots complement the main color. The intensity of the stains and shades depends on the weather conditions. The color of the corolla can vary during the inflorescence grows.

As a rule, the one-year observations are insufficient to estimate the habitus of plants. Overcoming of further growth and branching occurs under arid conditions and therefore very often does not allow us to establish the possibility of branching of the third and subsequent orders (Vlasova, 2013).

Data on the stability of morphological signs during the growing season are presented in the Table 1. 
Table 1 The evaluation of the morphological diversity of Lupinus angustifolius L. by growth stages

\begin{tabular}{|c|c|c|c|}
\hline $\begin{array}{l}\text { Decimal } \\
\text { score }\end{array}$ & Growth stages & Morphological signs & $\begin{array}{c}\text { Remarks about the } \\
\text { features of sign expression }\end{array}$ \\
\hline 0.9 & $\begin{array}{l}\text { - part of the seeding protruding } \\
\text { through the soil }\end{array}$ & $\begin{array}{l}\text { - color of cotyledons (abaxial } \\
\text { side) }\end{array}$ & $\begin{array}{l}\text { - the most contrasting at this } \\
\text { stage }\end{array}$ \\
\hline 1.0 & $\begin{array}{l}\text { - first pair of leaves protruding } \\
\text { beyond upright cotyledons }\end{array}$ & $\begin{array}{l}\text { - color of cotyledons (adaxial } \\
\text { side) }\end{array}$ & \\
\hline 1.10 & - 10 leaves emerged from bud & $\begin{array}{l}\text { - presence or absence } \\
\text { of anthocyanin around the } \\
\text { edges of leaflets }\end{array}$ & $\begin{array}{l}\text { - irregularly distinct at a later } \\
\text { stage }\end{array}$ \\
\hline 2.3 & $\begin{array}{l}\text { - bases of some basal leaves } \\
\text { clearly separated }\end{array}$ & $\begin{array}{l}\text { - stem color, the presence } \\
\text { or absence of the anthocyanin } \\
\text { on the stem }\end{array}$ & $\begin{array}{l}\text { - the most contrasting at this } \\
\text { stage }\end{array}$ \\
\hline 2.5 & $\begin{array}{l}\text { - bases of several leaves clearly } \\
\text { separated from each other }\end{array}$ & - leaf color, width of leaflets & $\begin{array}{l}\text { - the most contrasting at this } \\
\text { stage }\end{array}$ \\
\hline 3.3 & $\begin{array}{l}\text { - diverging standard petal } \\
\text { stage (anthesis) }\end{array}$ & - main color of corolla & - \\
\hline 3.5 & - coloured corolla stage & - color of corolla & $\begin{array}{l}\text { - maybe the appearance } \\
\text { of new stains or change } \\
\text { of corolla color (discolor } \\
\text { type) }\end{array}$ \\
\hline $3.3-3.5$ & $\begin{array}{l}\text { - from Diverging standard petal } \\
\text { stage (anthesis) to Coloured } \\
\text { corolla stage }\end{array}$ & $\begin{array}{l}\text { - presence or absence } \\
\text { of anthocyanin on peduncle } \\
\text { of flower raceme }\end{array}$ & - \\
\hline 4.4 & $\begin{array}{l}\text { - green pod, clear seed bulges } \\
\text { in pod walls, seeds filling all } \\
\text { space between septa }\end{array}$ & $\begin{array}{l}\text { - abundance of trichomes } \\
\text { on pods }\end{array}$ & $\begin{array}{l}\text { - the most contrasting at this } \\
\text { stage }\end{array}$ \\
\hline 4.9 & - pod turning khaki-coloured & $\begin{array}{l}\text { - color of pod surface, color } \\
\text { of endocarp }\end{array}$ & $\begin{array}{l}\text { - the most contrasting at this } \\
\text { stage }\end{array}$ \\
\hline \multirow[t]{2}{*}{5.9} & - seeds hard and harvest ripe & - color of seeds & - \\
\hline & - & - habit of plants & $\begin{array}{l}\text { - unlimited growth of plants } \\
\text { is fixed only in cool and wet } \\
\text { conditions }\end{array}$ \\
\hline
\end{tabular}

\section{Conclusions}

As a result, the available numeral system of lupin growth stages (Dracup and Kirby, 1996; Walker et al., 2011) was complemented with data of the estimated morphological traits and the peculiarities of their manifestation by growth stages in the above table.

We hope that the presented table would contribute to unification of monitoring of the morphological descriptions at a time of subjective visual perception. It can also help newcomers to properly assess the intraspecific diversity of Lupinus angustifolius L.

\section{References}

Dracup, M., Kirby, E.J., 1996. Lupin Development Guide. Nedlands WA: University of Western Australia Press, 97 p. ISBN 1-875560-66-1. 
Gladstones, J.S. 1967. Selection for economic characters in Lupinus angustifolius and L. digitatus. 1. Nonshattering pods. Australian J. of Experimental Agriculture and Animal Husbendry, vol. 7, p. 360-366. ISSN 0045-060X.

Kurlovich, B.S. 2002. Lupins. Geography, Classification, Genetic Researches and Breeding. St. Petersburg: Publicing house "Intan". 468 p. http://lupindiversity.blogspot.nl/

Stepanova, S., Nazarova, N., Korneichuk, V., Lehmann, Chr., Micolaichik, Ya. 1985. The international comecon list of descriptors for the genus Lupinus L. Leningrad, USSR, VIR, $46 \mathrm{p}$.

Vlasova, E.V. 2012. Problems to systematizations of Lupinus angustifolius L. spikelike types into VIR collection. NI Vavilov's ideas in the modern world. Abstracts. III Vavilov Int. Conf. 6-9 Nov. 2012, p. 53. ISBN 978-5-905954-04-7.

Vlasova, E.V. 2013. Problems of categorization of Lupinus angustifolius L. VIR-collection by type branching. Генофонд и селекция растений Том 1.: Полевые культуры: доклады и сообщения I межд. научнопракт. конф., Краснообск, 9-13 апреля 2013 г. СибНИИРС Россельхозакадемии, с. 108-114. ISBN 978-5-906143-25-9.

Vlasova, E.V. 2015. Morphological and taxonomic description of Lupinus angustifolius L. spikelike samples into VIR collection. Revista Botanică, vol. 1, no. 10, p. 88-91. ISSN 1857-095X.

Walker, J., Hertel, K., Parker, P., Edwards, J. 2011. Procrop Lupin Growth \& Development. Australia, State of New South Wales through NSW Department of Industry and Investment (Industry \& Investment NSW). District Agronomists. 84 p. ISBN 9781742560595.

Купцов, Н.С. 2001. Стратегия и тактика селекции люпина. Кормопроизводство, №1, с. 8-12. ISSN 0235-2540

Купцов, Н.С., Такунов, И.П. 2006. Люпин: генетика, селекция, гетерогенные посевы. Брянск, Клинцы «Белый город». 575 с. ISBN 5-88898-299-7.

Курлович, Б.С., Станкевич, А.К. 1990. Внутривидовое разнообразие трех однолетних видов люпина (Lupinus L.). Сборник научных трудов по прикладной ботанике, генетике и селекции, т. 135, с. 1934. ISSN 0202-3628. 